\title{
ETHICAL EDUCATION IN TEACHER STUDIES - PILOT STUDY ANALYSIS
}

\begin{abstract}
The following text presents the results of pilot studies on the condition of the ethical preparation of students of teaching faculties. A thesis was put forward that ethical competences are to a certain extent a set of specific skills that can and should be acquired and practiced during university preparation for the teaching profession. 50 students were included in the pilot study conducted using the diagnostic survey method in a form of a questionnaire. The hypothesis that students believe in importance of high ethical competence in the teacher's professional work was confirmed. Respondents indicated the changes required by university education in the discussed area and the desired transformations listed the need for solving practical problems in ethics classes. The project's author assumes current deficiencies in the preparation of future teachers for the performance of their professional work are related to the methods, and partly also to the content provided during ethics courses at universities.
\end{abstract}

Keywords: teacher education; ethics; ethical competence; higher education.

\section{Introduction}

In recent decades, there has been a significant departure from the axiological sphere in the discussion about education in Poland, also when it comes to training future teachers. Only few authors notice this tendency (Półturzycki, 2007; Suchodolski; 1990) with its negative effects. There has been a significant shift towards interest in improving competences in the process of preparing for the performance of teachers, but the question arises whether this is not a return to the technological trend in teacher education? Henryka Kwiatkowska (2008, p. 35) justifies that due to the vague nature of educational processes, their classification and detailed analysis is

* PhD Joanna Ludwika Pękala, the University of Warsaw, Poland, Faculty of Education; e-mail: jpekala@uw.edu.pl. 
not possible. She points out that the empirical study of teacher activities will allow only for a partial description of pedagogical practice.

On the other hand, a one-way perception of the teaching profession as a profession which defies all research and attempts at systematization can result in not drawing in-depth conclusions from educational practice and, as a consequence, inadequate preparation of students of pedagogy for their future professional work. This fear seems particularly justified when it comes to improving their knowledge and skills in the area of ethics characterized by such a significant impact on all activities of future teachers. Elizabeth Campbell (2008, p. 358) stresses this format of teacher preparation programs is necessary because "ethics and teaching seem inherently compatible and unavoidably intertwined".

\section{Theoretical justification for the planned research}

Research on the teaching profession proves the presence of ethical requirements in a set of social expectations for pedagogical representatives of the profession. What is more, the expectations even apply to the private lives of teachers (Pękala, 2017). This is because many of the competencies necessary to practice this profession are related to the sphere of attitudes, i.e. the personal value system. It is impossible to separate professional and personal values, especially in this profession, due to the huge number of decisions made by teachers (Ozolins, 2005, p. 360), sometimes without time for reflection and any possible correction. Michael Malone has observed that majority of teachers function in a way considered moral, even though they had not received any formal education in ethics. He realizes however that teachers are occasionally close to crossing the line of ethical or fair play demeanor. They may be "cheating; plagiarism; bullying; misrepresentation of facts; fabricated data/test scores; inappropriate treatment of students or colleagues" (Malone, 2020, p. 77). On the one hand these forms of behavior are hard to spot. We cannot even label them as detrimental. On the other hand an attempt to mitigate negative behawior may additionally shutter a shaky prestige of the teaching job. For that reason modern researchers pay attention to the strong link between educational activities and the sphere of ethical values by stressing the need to educate student teachers in this area (Maxwell \& Schwimmer, 2016; Nunes, 2016; Ozolins, 2005).

Unfortunately, the axiological dimension of teaching profession both in the literature and in the process of education, quite often was treated only in as "recommendations". This sphere was described in a very general way, in the form of expectations about the resources that the teacher was to provide as a ready set. There was no answer in the literature to the question where these resources would come from. What competencies should be included in the group of ethics skills that characterize a particular teacher?

Piaget, Kohlberg, Hoffman, Erickson, or Muszyński prove that moral development is built on stages. Each of them obviously recognizes different levels 
of the process. This does not mean that only the labels and characteristics of certain levels change. Attempts to describe the sources and even ways of creating this type of behavior prove that ethical competences are, to put it simply, a set of specific skills (Benner et al., 2010; 2016; Rest, 1982; Rest \& Narvez, 1994). Thus, the skills can be improved during the education process, including at university level. John Ozolins (2005) draws our attention to the fact that it is not enough to equip students with a specific "resource" of value. Similarly to Benner et al. (2010) I would like to point out that future teachers must not only know certain codes about morality, but must understand them. This understanding requires answering many questions, some of which are presented below:

- where do certain values come from (we are talking here not only about the philosophical source, but also about our own personal moment of creation or acceptance),

- what was the reason for their creation or acceptance,

- what is the justification for specific values (for me, but also in a broader, ethical context, how do the two sources relate to one another),

- how is a given value correlated to laws, customs, culture in which I live (and within other cultural groups),

- what are the consequences of acting in accordance with them or being incompatible with them?

The author of this article ventures to find the answer to the question whether the process of educating students of pedagogical faculties tends to equip them with specific knowledge, skills and attitudes in the area of ethics? How do students themselves perceive the importance of ethical teacher preparation and the quality of ethics courses proposed at the universities where they study? Further in the article, the concept of the main study will be presented, along with organization and methodology of the pilot study.

\section{Methodological concept}

Despite the fact that the National Qualifications Framework for Higher Education lists ethical competences at every level of the learning outcomes described there, teaching ethics at higher schools of education in Poland is not a common practice. According to the hypothesis presented in the described research, even if the ethical preparation of candidates for the teaching profession is included in the package of courses proposed to students of education, it takes the form of classes in the history of philosophy with elements of pedagogical ethics. In an attempt to clarify whether the perceived deficiencies are merely presumptions or whether they are confirmed in the educational reality of universities and other colleges, the following studies were designed. 
Research goal and issues

The purpose of this research is to obtain information on the state of ethical education of future teachers ${ }^{1}$. The researchers would like to understand the students' take on the ethics-related classes offered by their schools and the respondents' attitude towards these courses. Following are three main research questions required to reach the research goal: (1) What is the quality of the Ethics courses offered by your university? (2) Do they educate in all dimensions of teaching qualifications (knowledge, skills, attitudes - social competences)? (3) What are the needs of students of teaching faculties in the area of ethical education?

\section{Research area and study group}

The planned research will be carried out in Warsaw, where there is the largest number of public and private universities in Poland offering teacher's studies. The following departments were taken into account: those granting the right to teach various subjects in schools (e.g. Polish, mathematics, biology, history) and preparing for work in early childhood and pre-school education.

The study group will consist of students and lecturers. University employees who teach classes in philosophy, ethics or related subjects were selected for the study. The main study will be preceded by a sample calculation.

\section{Research methods}

The first stage of basic research will be a review of curricula and education plans of selected universities for the presence or absence of ethics classes. This step is going to provide data about the educational offer of each of the surveyed universities. It will make it possible to check to what extent a particular university implements its own assumptions and will be an opportunity to juxtapose the lecturers' declarations of selected universities with the programs of the schools in which they are employed.

Then it is planned to carry out a diagnostic survey2 using the author's survey form. It will be presented to two groups of respondents, faculty and students. The designed tool is to examine opinions and needs (of both students and lecturers) in the area of ethical education and how they are met at the university of their choice. This selection was made so that it would be possible to collate the opinions of two educational entities - one responsible for planning educational processes and the teaching itself, the other being the addressees of the educational programs.

1 This is the purpose set out for the main studies described, only in part for the pilot studies.

2 In the pilot study, work was limited to this part only, except for the analysis of university programs and syllabuses. 


\section{Pilot study - substantive justification and organization}

The conduct of the actual analysis was preceded by a preliminary pilot study. The expediency of piloting is most often justified by methodological reasons, and therefore the necessity of the following:

- verification of research problems,

- checking the research tool,

- defining the organizational and technical aspects of the study,

- creating procedures for the subsequent analysis of the results of relevant tests (Sztabiński \& Sztabiński, 2004, pp. 56-57).

The study described was also accompanied by substantive premises specific to the initial type of trial type and it was "checking the adopted method of the research concept operationalization" (Sztabiński \& Sztabiński, 2004, p. 57). In particular, research problems, substantive construction of the designed study and the tool itself were analyzed.

The pilot study covered by this description was conducted in May 2019. The study group consisted of 50 students of the Education Studies of the University of Warsaw. Among the respondents, 27 persons are undergraduate participants, 23 respondents are doing their MA programs. The respondents in the described trial study constitute approx. $5 \%$ of the test group selected for the actual research.

\section{Preliminary research conclusions}

At the initial stage of the survey, questionnaires were selected taking into account only those in which the respondents answered in the affirmative to the question about participation in philosophy or ethics classes during their current studies. 45 were compulsory course, while 15 were optional classes ${ }^{3}$.

In the main part of the study, students were asked to assess the knowledge, skills and competences acquired through their participation in the courses. Each of the three levels had detailed components assigned, and so for knowledge they were: (1) Selected issues in the history of ethics. (2) Selected problems of metaethics. (3) Teacher professional ethics. (4) Fundamentals of the didactics of ethics. (5) Transfer of moral knowledge in relation to human developmental stages.

3 In this question, the respondents had the possibility of multiple choices, therefore the total of the answers exceeds the number of respondents (50), i.e. the initial $100 \%$. 
Table 1. Assessment of learning outcomes at the knowledge level [in percentage]

\begin{tabular}{|l|c|c|c|c|c|}
\hline \multicolumn{1}{|c|}{ a) Knowledge } & $\begin{array}{c}\text { very } \\
\text { high }\end{array}$ & high & medium & low & very low \\
\hline selected issues of ethics history & 14 & 32 & 30 & 10 & 10 \\
\hline selected problems of metaethics & 4 & 20 & 40 & 8 & 22 \\
\hline teacher professional ethics & 8 & 28 & 36 & 22 & 2 \\
\hline basics of the didactics of ethics & 2 & 32 & 38 & 16 & 8 \\
\hline $\begin{array}{l}\text { transfer of moral knowledge in re- } \\
\text { lation to human developmental stages }\end{array}$ & 4 & 26 & 44 & 16 & 6 \\
\hline
\end{tabular}

Source: own elaboration

As the data in Table 1 shows, students rated the learning outcomes in the field of ethics history the highest. Admittedly, the same number, i.e. $32 \%$ of responses, also indicated a high grade for content related to the didactics of ethics, but the totals of each of the first two columns (high and very high grades) are significantly different. The history of ethics obtained $46 \%$ of grades belonging to the two highest registers, while in the case of knowledge in the field of the didactics of ethics it is only $34 \%$ of responses.

Further analysis shows that these are not accidental results and are confirmed by the open question about the changes that students believe should be made in the ethical education of future teachers. Respondents pointed out that too much time is devoted to the transfer of theoretical knowledge related to various philosophical trends, which limits the possibility of shaping students' skills. Therefore, the conclusion is that a high assessment of effects in terms of knowledge is not synonymous with student satisfaction, and therefore a sense that their needs related to ethical education have been met.

Regarding educational outcomes in the area of skills acquisition, the following components have been identified to better illustrate results within this level: (1) Observation, interpretation and analysis of social phenomena in the ethical aspect. (2) Self-analysis of own pedagogical skills. (3) Class evaluation. (4) Shaping the moral sensitivity of children and adolescents. (5) Monitoring student's moral development.

Table 2. Assessment of learning outcomes at the skill level [in percentage]

\begin{tabular}{|l|c|c|c|c|c|}
\hline \multicolumn{1}{|c|}{ b) skills } & $\begin{array}{c}\text { very } \\
\text { high }\end{array}$ & high & medium & low & $\begin{array}{c}\text { very } \\
\text { low }\end{array}$ \\
\hline $\begin{array}{l}\text { observation, interpretation and } \\
\text { analysis of social phenomena in the } \\
\text { ethical aspect }\end{array}$ & 2 & 28 & 48 & 16 & 2 \\
\hline $\begin{array}{l}\text { self-analysis of own pedagogical } \\
\text { skills }\end{array}$ & 8 & 34 & 30 & 22 & 2 \\
\hline
\end{tabular}




\begin{tabular}{|l|c|c|c|c|c|}
\hline \multicolumn{1}{|c|}{ b) skills } & $\begin{array}{c}\text { very } \\
\text { high }\end{array}$ & high & medium & low & $\begin{array}{c}\text { very } \\
\text { low }\end{array}$ \\
\hline class evaluation & 4 & 26 & 54 & 8 & 4 \\
\hline $\begin{array}{l}\text { shaping the moral sensitivity of } \\
\text { children and adolescents }\end{array}$ & 10 & 36 & 30 & 14 & 6 \\
\hline $\begin{array}{l}\text { monitoring student's moral } \\
\text { development }\end{array}$ & 2 & 26 & 46 & 18 & 4 \\
\hline
\end{tabular}

Source: own elaboration

The results related to the skills acquisition, which according to students are (or were in the case of completed courses) shaped in ethics classes, seem to be ambiguous. The highest marks were obtained by the ability to shape the moral sensitivity of children and youth, as well as self-analysis of own pedagogical skills. Some components have a significant correlation with the self-reflection of a teacher and efficiency in shaping it among students, making this score more optimistic. However, there is a doubt particularly related to the main purpose of the pilot study: to what extent are the questions formulated in the survey understandable to the respondents - is their substantive level appropriate for the respondents, do the respondents understand the concepts contained in the survey form as meant by its author? Therefore, having analyzed the results of the pilot study within this question, it can be assumed that we are dealing with one of the two options described below:

- in this question, the respondents chose the responses that were most understandable to them, not the phrases that described the skills acquired in class,

- the respondents chose responses consistent with the facts, i.e. related to the subjectively perceived effects of the classes in which they participated.

It seems that the first of the above-mentioned situations could have taken place when this question was answered. As mentioned earlier, the studies described are preliminary but also experimental. The reasonableness of the research concept itself as well as the accuracy and purposefulness of the prepared tool are verified. The surveyed students were asked to complete the provided questionnaire, as well as to mark phrases that they did not understand. In the case of the question regarding skills, the respondents rated the components that were previously indicated as formulations incomprehensible the lowest. It seems, therefore, that the results obtained for this question ${ }^{4}$ should provide not only substantive but also methodological conclusions regarding the construction of the research tool, in particular the wording contained in it (this issue will be raised again in the final part of the article).

4 The survey question was: How high do you assess the implementation of learning outcomes (applies to classes in ethics or a related subject). 
The third and final part of the analyzed question concerned social competences, and as regards this level, the following specific components were identified: (1) Ethical analysis of own activities and the activities of teams managed by the teacher. (2) Knowledge of cultural codes of behaviors of different nations. (3) Distinguishing dominant beliefs in individual social structures. (4) Cultivating and disseminating patterns of proper behavior in a professional environment. (5) Initiating actions for the public good.

Table 3. Assessment of learning outcomes at the level of social competences [in percentage]

\begin{tabular}{|l|c|c|c|c|c|}
\hline \multicolumn{1}{|c|}{ c) social competence } & very high & high & medium & low & very low \\
\hline $\begin{array}{l}\text { ethical analysis of own activities and } \\
\text { the activities of the teams managed }\end{array}$ & 4 & 34 & 34 & 18 & 6 \\
\hline $\begin{array}{l}\text { knowledge of cultural codes of beha- } \\
\text { viors of various nations }\end{array}$ & 0 & 32 & 44 & 12 & 10 \\
\hline $\begin{array}{l}\text { distinguishing dominant beliefs in } \\
\text { individual social structures }\end{array}$ & 4 & 32 & 38 & 16 & 4 \\
\hline $\begin{array}{l}\text { cultivating and disseminating pat- } \\
\text { terns of proper behavior in a profes- } \\
\text { sional environment }\end{array}$ & 10 & 34 & 38 & 8 & 6 \\
\hline $\begin{array}{l}\text { initiating activities for the public } \\
\text { good }\end{array}$ & 6 & 26 & 36 & 22 & 6 \\
\hline
\end{tabular}

Source: own elaboration

As the results in Table 3 show, the highest rating was given to the competence related to the dissemination of patterns of proper behavior in a professional environment. The lowest scores were obtained by the capability to initiate actions for the public good, but there are not any significant differences in percentage.

Moving on to the overall assessment of learning outcomes in ethics and related subjects, the differentiation is not significant and it amounts to $1-3 \%$ in the same ranges of the scale (very high, high, medium, low and very low), as compared with the results for levels of knowledge, skills and competences (Table 4).

Table 4. Overall assessment of learning outcomes at three levels [in percentage]

\begin{tabular}{|l|c|c|c|c|c|c|}
\hline & no answer & very low & low & on average & \multicolumn{1}{c|}{ high } & very high \\
\hline a) knowledge & 4,4 & 9,6 & 14,4 & 37,6 & 27,6 & 6,4 \\
\hline b) skills & 4,0 & 3,6 & 15,6 & 41,6 & 30,0 & 5,2 \\
\hline $\begin{array}{l}\text { c) social } \\
\text { competences }\end{array}$ & 4,0 & 6,4 & 15,2 & 38,0 & 31,6 & 4,8 \\
\hline
\end{tabular}

Source: own elaboration 
What does this lack of significant differences indicate? As mentioned earlier, it can prove that respondents do not fully understand the terms used in the survey. The second alleged reason for the lack of differentiation in respondents' responses is the occurrence of the central tendency phenomenon related to simplifications in human perception and assessment. Choosing the medium values or avoiding extreme assessments according to researchers indicates the adaptive functions of our brain and is associated with the construction of ways responsible for brain function in the conditions of information noise (Dube, 2019). Such a phenomenon could take place in the case of the described study due to the fact that each of the levels was divided into several components, which gave students a lot of, perhaps not fully understood, elements to choose from.

Respondents were also asked how they assessed the usefulness of ethics classes for their future professional work (Table 5).

Table 5. Assessment of the suitability of ethics classes for future professional work [in percentage]

\begin{tabular}{|c|c|c|c|c|}
\hline no opinion & not useful & somehow useful & useful & very useful \\
\hline 2 & 18 & 30 & 40 & 10 \\
\hline
\end{tabular}

Source: own elaboration

Only $10 \%$ of respondents assessed the courses as very useful, $40 \%$ of the respondents as useful. As shown in the table above (Table 5), less than half of the students surveyed assessed ethics classes proposed by their universities as somehow useful or not useful. The comparison of the above results with the analyses regarding the importance of teacher's moral and ethical competences in the opinion of students (Table 6) is self-explanatory.

Table 6. Assessment of the importance of ethical competences in teachers' professional work [in percentage]

\begin{tabular}{|c|c|c|c|c|}
\hline no opinion & unimportant & $\begin{array}{c}\text { of little } \\
\text { importance }\end{array}$ & important & $\begin{array}{c}\text { very } \\
\text { important }\end{array}$ \\
\hline 2 & 0 & 2 & 36 & 60 \\
\hline
\end{tabular}

Source: own elaboration

Students recognize the great importance of ethical skills in pedagogical work $60 \%$ of respondents consider them very important, for $36 \%$ they are important. However, it seems that the respondents are not entirely satisfied with the classes they attend. Even if the understanding of the concepts contained in the survey was incomplete or a central tendency error occurred, the respondents' hesitation regarding the quality of ethics classes is noticeable in the preliminary results. The analyses presented above confirm that students appreciate the importance of moral 
and ethical competences in the work of a teacher $-96 \%$ of the responses stating that the skills are important or even very important confirm this hypothesis.

Next, the respondents were asked whether there should be changes in the ethical education of future teachers (Table 7).

Table 7. Responses of respondents to the question about the need to make changes in ethical education in teacher studies [in percentage]

\begin{tabular}{|c|c|c|}
\hline yes & no & I have no opinion \\
\hline 46 & 8 & 46 \\
\hline
\end{tabular}

Source: own elaboration

Respondents were divided in their opinions, but they were not two clearly antagonistic groups. Less than half of them believe that steps should be taken towards the transformation of ethics classes and the same number of respondents (46\%) replied that they have no opinion. The respondents' previous answers clearly show that they are not fully satisfied with the results of the ethics classes they attended, but they can see the significance of them for their future professional work. It seems that students are able to correctly assess the courses of which they are active recipients, they only lack the knowledge and experience to indicate in which direction changes should go.

The open question ${ }^{5}$ on the same issue revealed the specific opinions of the surveyed students, and it should be noted that not all respondents took advantage of the opportunity to speak up. The respondents who decided to express their opinions on the need for introducing changes in the ethical education of future teachers constituted $44 \%$ of the study group. The directions of changes pointed out by students concerned:

- number and length of courses - according to respondents, there should be more of them, classes should be conducted continuously for several years of study (see Nunes 2016, p. 113);

- working methods - students are interested in active participation in classes developing practical skills;

- forms of work - respondents would like to participate in courses implemented in small groups;

- content - students would be interested in classes during which real difficult cases from pedagogical practice would be discussed, they would like to learn how to talk to children about ethics, in particular about respect and tolerance, various cultural codes, they would like to implement selfreflection (Ozolins, 2005 p. 360).

In most student statements, there were suggestions about the need for limiting the content related to the history of philosophy in favor of some practical knowledge

5 The question was: „What should be changed in the area of ethics education in teacher training?” 
of ethics. Respondents indicated three parties in this question: themselves - the future teacher, pupils, and parents. As a consequence they noticed the need for acquiring the skills of self-reflection and ethical communication during studies.

\section{Summary and further research intentions}

The described pilot studies, due to these two characteristics, resulted in two types of conclusions: 1. They confirmed the method of the research concept operationalization, and therefore the advisability of the posed research questions. Also, some hypotheses such as the one regarding the necessity of a pragmatic approach to the design and implementation of didactic intentions in ethics classes for future teachers were confirmed in the preliminary analyses. 2. A change should be made within the research tool. Tasks in the survey form must be ordered in such a way that questions about learning outcomes are preceded by a verification and certain systematization of the respondents' knowledge about the examined issue. Thus, respondents start assessing the knowledge, skills and social competences acquired in class by assigning individual components of each level to their definitions. This will allow us to assess the knowledge of the respondents to the question about learning outcomes. The lack of this type of analysis makes it hard to conclude whether the respondents' assessments always took medium values due to a central tendency error or resulted from incomplete understanding of the wording in the survey. In the opinion of the author of this text, as well as of other researchers (Ozolins, 2005; Nunes, 2016; Benner et al., 2010), it is the understanding of the values underlying ethically marked action that guarantees such behavior. Perhaps the responses provided were a true reflection of the views of the respondents, but the use of tasks with matching definitions for individual components will significantly objectify the results of research.

Our pilot study is the basis for conducting the actual study. Initial research activities described in this article justify the purpose of the research problems. Students recognize the great importance of ethical competence in the work of educators, but they indicate the need for making changes in the ethical education of future teachers. Thus, respondents' statements confirm Allan Hutchinson's belief that ethical education is to be an active challenge. According to this researcher (Hutchinson, 1999, p. 303), teaching ethical reasoning is the basis of ethical education at a university, which is a process immersed in a sociopolitical context, from which a lot of controversy arises, but also solutions. It should be remembered that the teacher training prepares students for pedagogical activities in a world full of the differentiations so that they could also teach children how to make decisions related to social life. Even if we assume that "true education must be an education in criticism" (Singh \& Stückelberger [Eds.] 2017, p. 23), we need free and critically thinking teachers who know how to share the skills with their students. This is the reason teachers should receive a thorough training in ethics. Ethics need not be 
confined to morality but also embrace reflection about the world and self. It should be an instrument for a positive transformation. According to Ozolins (2005, p. 359), classes in ethics is more than a course involving the development of knowledge and skills understood as cognitive achievements. It is a "self-training". Students confirmed what the researchers and the author of this text believe, complaining about excessive amount of theory and insufficient portions of hands-on activities. Our research shows that changes in ethical education for university students requires changes. Students should know how to face real issues encountered during the didactic and educational process.

Further research will be conducted in Warsaw. It will cover a representative group of students of teaching faculties at all universities in the city, which will enable drawing conclusions regarding the quality of ethical education. The author hopes that the analyses will create an introduction to nationwide research that will allow generalizing results nation-wide.

\section{References}

Benner, D., Heynitz, M., Ivanov, S., Nikolova, R., Pohlmann, C., \& Remus, C. (2010). Ethikunterricht und moralische Kompetenz jenseits von werte- und Tugenderziehung. Zeitschrift für die Didaktik der Philosophie und Etik, 4(32), 304-312.

Campbell, E. (2008). The Ethics of Teaching as a Moral Profession. Curriculum Inquiry, 38(4), 357-385.

Dube, C. (2019). Central tendency representation and exemplar matching in visual short-term memory. Memory \& Cognition, 47(4), 58-602.

Hutchinson, A. C. (1999). Beyond black - letterism: Ethics in law and legal education. The Law Teacher, 33(3), 301-309.

Madalińska-Michalak, J., Jeżowski, A. J., \& Więsław, S. (2017). Etyka w systemie edukacji w Polsce. Warszawa: Wolters Kluwer.

Malone, M. (2019). Ethics education in teacher preparation: a case for stakeholder responsibility. Ethics and Education, 15(4), 1-21.

Maxwell, B., \& Schwimmer M. (2016) Professional ethics education for future teachers: A narrative review of the scholarly writings. Journal of Moral Education, 45(3), 354-371.

Nunes Barbosa, E. M. (2016). The teaching of ethics in higher education schools: The reality of a Portuguese institution. The Małopolska School of Economics in Tarnów Research Papers Collection, 32(4), 111-121.

Ozolins, J. (2005). Teaching ethics in higher education. Australia: Higher Education Research and Development Society of Australasia.

Pękala, J. (2017). Etos nauczycieli - mit czy rzeczywistość? Warszawa: Wydawnictwa Uniwersytetu Warszawskiego. 
Półtużycki, J. (2007). Aksjologia i dydaktyka w rozwoju teorii edukacyjnej. In A. Świrko-Pilipczuk (Ed.), Dydaktyka ogólna i nauki z niq współdziałające. Szczecin: Zapol.

Rest, J.(1982). A psychologist looks at the teaching of ethics. The Hastings Center Report, 12(1), 29-36.

Rest, J., \& Narvez, D. (1994). Moral development in professions: Psychology and applied ethics. Retrieved from https://psycnet.apa.org/record/1994-98768-ooo.

Rozporzadzenie Ministra Nauki i Szkolnictwa Wyższego z dnia 14 listopada 2018 w sprawie Krajowych Ram Kwalifikacji dla Szkolnictwa Wyższego.

Singh, D., \& Stuckelberger, C. (Eds.) (2017). Ethics in Higher Education. Values - driven Leaders for the Future. Globethics net. Retrieved from: https://www. globethics.net/documents/4289936/20368389/GE_Education_Ethics_1_ isbn9782889311644.pdf.

Suchodolski, B. (1990). Wychowanie mimo wszystko. Warszawa: Wydawnictwa Szkolne i Pedagogiczne.

Sztabiński, P. B, \& Sztabiński, F. (2004). Jak połączyć pilotaż z badaniem próbnym? Przykład Europejskiego Sondażu Społecznego 2004. Acta Universitatis Lodziensis. Folia Sociologica, 14 (2), 113-141.

\section{KSZTALCENIE ETYCZNE NA STUDIACH DLA NAUCZYCIELI - ANALIZA BADANIA PILOTAŻOWEGO}

Streszczenie: $\mathrm{W}$ artykule przedstawiono wyniki badań pilotażowych odnośnie stanu przygotowania etycznego studentów nauczycielskich kierunków studiów. Autorka formułuje tezę, że kompetencje etyczne to w pewnym uproszczeniu zestaw konkretnych umiejętności, które można i powinno się nabywać oraz ćwiczyć podczas uniwersyteckiego przygotowania do wykonywania zawodu nauczyciela. Pilotażem zostało objętych 50 studentów, badanie przeprowadzono za pomocą metody sondażu diagnostycznego z wykorzystaniem kwestionariusza ankiety. Potwierdzono hipotezę dotyczącą przekonania studentów o dużym znaczeniu kompetencji etycznych w pracy zawodowej nauczyciela. Respondenci wskazali zmiany, jakich wymaga kształcenie uniwersyteckie w omawianym zakresie i wśród pożądanych przekształceń wymieniono potrzebę rozwiązywania praktycznych problemów na zajęciach z etyki. Zgodnie z przypuszczeniami autora projektu, obecne braki w przygotowaniu przyszłych nauczycieli do wykonywania ich pracy zawodowej są związane $\mathrm{z}$ metodami, a po części także $\mathrm{z}$ treściami przekazywanymi podczas kursów etyki w szkołach wyższych.

Słowa kluczowe: kształcenie nauczycieli; etyka; kompetencje etyczne; szkolnictwo wyższe. 